\title{
STRESS DAN TEKANAN DARAH PADA PASIEN HIPERTENSI
}

\author{
Agustina Boru Gultom \\ Jurusan Keperawatan Poltekkes Kemenkes Medan
}

\begin{abstract}
Abstrak
Masalah kesehatan yang berkaitan dengan peningkatan tekanan darah yang terjadi pada pasien hipertensi masih sering dialami oleh masyarakat baik diIndonesia sebagai negara yang sedang berkembang maupun dinegara-negara maju. Masalahnya berhbungan dengan dampak peningkatan tekanan darah terhadap masalah jantung, saraf dan ginjal. Banyak kondisi yang dapat menimbulkan peningkatan tekanan darah, dimana stress merupakan salah satu kondisi yang dapat merangsang sistem saraf simpatis, meningkatkan tahanan pembuluh darah dan akhirnya meningkatkan tekanan darah, Tujuan penelitian ini adalah untuk menganalisis hubungan stress demgan tekanan darah pada pasien hipertensi. Jenis penelitian kuantitatif dengan desain penelitian korelasi dengan sampel berjumlah 36 responden pasien hipertensi melalui tehnik consecutive sampling. Hasil penelitian menunjukkan bahwa ada hubungan stress dengan tekaaan darah sistolik pada pasien hipertensi dengan $p$ value 0,000 , ada hubungan stress dengan tekanan darah diastolik pada pasien hipertensi dengan $p$ value 0,014 .
\end{abstract}

Kata kunci : Sress, Tekanan Darah

\section{PENDAHULUAN}

Tekanan darah yang meningkat seringkali terjadi pada masalah kesehatan yang disebut dengan hipertensi. Penyakit ini merupakan kondisi gangguan kesehatan yang biasa muncul dimasyarakat dengan teknologi yang sedang berkembang atau teknologi yang sudah maju.

Hipertensi merupakan isu kesehatan masyarakat yang sering muncul dipermukaan. Hipertensi dapat menjadi faktor resiko yang paling penting pada masalah jantung koroner, gagal jantung, stroke dan gagal ginjal. (LeMone et al, 2011)

Hasil penelitian menunjukkan secara konstan manfaat pasien dalam mengurangi tekanan darahnya. Sebagai contoh, suatu penurunan pada tekanan darah sistolik $10 \mathrm{mmHg}$ adalah berhubungan dengan $22 \%$ penurunan penyakit jantung koroner dan $41 \%$ penurunan peyakit stroke, dan $41-46 \%$ penurunan kematian akibat metabolik jantung. (WHO, 2014).

Banyak faktor yang dapat memicu dalam peningkatan tekanan darah pada pasien hipertensi. Salah satu faktor yang mendapat perhatian adalah faktor stress. Stress dapat memiliki dampak pada masalah fisik, emosi, intelektual, sosial dan spiritual. Dampak pada masalah fisik adalah dapat mengancam homeostatis fisiologi seseorang. Namun respon terhadap stress bervariasi, bergantung paada persepsi individu terhadap peristriwa. Secara emosi, stress dapat menimbulkan perasaan negatif atau tidak membangun terhadap diri sendiri. (Kozier et al, 2004).

Stress menstimulasi sistem saraf simpatis, meningkatkan vasokonstriksi, meningkatkan resistensi vaskuler sistemik, frekuensi dan curah jantung, meningkat untuk transpor nutrien dan produk sisa metabolisme serta meningkatkan tekanan darah. Stress fisik dan emosional menyebabkan kenaikan sementara tekanan darah dimana stress yang sering atau terjadi secara terus menerus dapat menyebabkan hipertropi otot polos pembuluh darah atau mempengaruhi jalur integratif sentral otak. (LeMone et al, 2011; Kozier et al, 2004). Stress atau ketegangan yang kronis yang disebabkan secara khusus akibat minimnya kemampuan pasien didalam berespon terhadap stress yang menimpa dirinya akan menyebabkan pasien mengalami peningkatan tekanan darah.(Sparrenberger et al, 2009).

Hasil penelitian Levenstein et al (2001) menggambarkan bahwa stress psikososial dapat meningkatkan insidensi hipertensi terutama pada wanita. Hasil penelitian Prabowo (2005) mengenai hubungan stress dengan kejadian hipertensi pada pasien rawat inap rumah sakit dr.Oen Surakarta juga memperlihatkan korelasi yang bermakna antara stress dengan kejadian hipertensi dengan $p$ value 0,0001 .

Berdasarkan survey pendahuluan yang peneliti lakukan pada Puskesmas Muliorejo Kabupaten Deli Serdang, didapat dari tenaga kesehatan bahwa kasus hipertensi merupakan 10 kasus penyakit terbesar, dan pasien hipertensi menggunakan obat-obatan anti hipertensi serta adanya pasien hipertensi mengalami ketegangan atau stress didalam kehidupannya seharihari.

\section{METODE PENELITIAN}

Jenis penelitian ini adalah penelitian kuantitatif dengan desain penelitian korlaso (Dahlan, 
2009). Penelitian dilaksanakan pada bulan Mei sampai dari Juli 2017. Populasi dalam penelitian ini adalah seluruh pasien hipertensi yang berobat dipuskesmas dengan besar sampel menggunakan rumus besar sampel tunggal minimal pada uji hipotesis menggunakan koefisien korelasi (r) (Sastroasmoro dan Ismail,2008) :

$$
\mathrm{n}=\left(\frac{\mathrm{z} \alpha+\mathrm{z} \beta}{0.5 \ln (1+\mathrm{r}) /(1-\mathrm{r})}\right)^{2}+3
$$

Tingkat kemaknaan atau tingkat kepercayaan $(\alpha)$ dan power penelitian $(z \beta)$ ditetapkan oleh peneliti Tingkat kepercayaan yang dikehendaki sebesar $99 \%$ dengan $\alpha=0,05$ sehingga $z \alpha=1,960$. Power penelitian ditetapkan sebesar $90 \%$, sehingga $z \beta=1,282$. Nilai $r$ adalah perkiraan koefisien korelasi yang telah ada yang didapatkan dari studi kepustakaan. (Sastroasmoro dan Ismail,2008). Pada studi kepustakaan didapatkan koefisien korelasi stress dengan kualitas hidup hipertensi sebesar 0,593 (Evita dkk, 2017), sehingga nilai $\mathrm{r}$ inilah yang digunakan dalam menghitung rumus besar sampel.

$$
\mathrm{n}=\left(\frac{, 960+1,282}{0.5 \ln (1+0,593) /(1-0,593)}+3^{2}=36\right. \text { sampel }
$$

Tehnik pengambilan sampel adalah consecutive sampling yaitu semua subjek yang datang dan memenuhi kriteria pemilihan dimasukkan dalam penelitian sampai jumlah subjek yang diperlukan (Sastroasmoro\&Ismail,2008). Adapun kriteria sampel pada penelitian ini adalah pasien yang mengalami hipertensi dengan peningkatan tekanan darah $\geq$ 140/90 $\mathrm{mmHg}$, penggunaan minimal 1 jenis obat hipertensi, memiliki kesadaran penuh dan tidak mengalami disorientasi tempat, waktu dan orang, dapat berkomunikasi dengan menggunakan bahasa Indonesia yang baik, bersedia menjadi responden

Variabel penelitian meliputi stress yaitu: seberapa jauh responden merasakan diri mereka dalam keadaan tidak dapat diprediksi, tak terkontrol dan kelebihan beban, diukur dengan kuesioner Perceived Stress Scale dengan 10 pertanyaan memuat 5 interval jawaban 0-4, terdiri dari $0=$ tidak pernah, 1 = hampir tidak pernah, 2 = kadang-kadang, 3 = sering, 4 = sangat sering (Cohen,1984), dan tekanan darah yaitu sistolik diukur pada saat terdengar suara pembuluh darah yang tiba-tiba mengembang setelah kolaps,atau saat suara pertama kali mulai terdengar di stetoskop, dan tekanan darah sistolik diukur pada saat hilangnya suara, diukur dengan tensi meter sphygmomanometer merk Nova dan stetoskop Litman. Metode pengumpulan data adalah setelah mendapat izin, pencarian responden dimulai dengan melihat data nama pasien hipertensi yang ada dalam catatan di Puskesmas, kemudian bersama dengan tenaga kesehatan merencanakan untuk pengambilan sampel penelitian. Pada saat pengumpulan data, peneliti menjelaskan tentang manfaat penelitian, prosedur penelitian kepada calon responden untuk mengikuti penelitian dan yang bersedia berpartisipasi diminta untuk menandatangani lembar persetujuan (Informed Consent). Responden yang bersedia mengikuti penelitian dan memenuhi kriteria penelitian dilakukan pengukuran stress menggunakan kuesioner dan tekanan darah menggunakan tensi meter sphygmomanometer merk Nova dan stetoskop Litman. Aspek pengukuran stress, dan tekanan darah adalah menggunakan skala ratio. Data dilolah secara statistik dengan menggunakan software SPSS. Analisa univariat berupa nilai minimum, nilai maximum, mean dan standar deviasi. Analisa data bivariat yaitu untuk mengetahui hubungan stress dengan tekanan darah dengan uji pearson jika data berdistribusi normal dengan tingkat kemaknaan ( $\alpha)=0,05$ dimana dikatakan bermakna bila $\mathrm{p}<0,05$, jika tidak data berdistribusi normal dengan uji spearman. (Dahlan,2009).

\section{HASIL PENELITIAN}

\section{Analisa Univariat \\ Karakteristik Responden}

Karakteristik responden dalam penelitian ini meliputi jenis kelamin, umur, status perkawinan, pendapatan, pekerjaan dan lama menderita hipertensi.

\begin{tabular}{|c|c|c|}
\hline Variabel & Frekuensi & Total (\%) \\
\hline \multicolumn{3}{|l|}{ Jenis Kelamin } \\
\hline Laki-laki & 5 & $13,9 \%$ \\
\hline Perempuan & 31 & $86,1 \%$ \\
\hline \multicolumn{3}{|l|}{$\underline{\text { Umur }}$} \\
\hline$\overline{35-44}$ & 2 & $5,6 \%$ \\
\hline $45-59$ & 17 & $47,2 \%$ \\
\hline $60-74$ & 14 & $38,9 \%$ \\
\hline $75-90$ & 3 & $8,3 \%$ \\
\hline \multicolumn{3}{|l|}{ Status Perkawinan } \\
\hline Menikah & 24 & $66,7 \%$ \\
\hline Duda/Janda & 12 & $33,3 \%$ \\
\hline \multicolumn{3}{|l|}{ Pendapatan } \\
\hline$>2.271 .500-4.500 .000$ & 5 & $13,9 \%$ \\
\hline$\leq 2.271 .500$ & 31 & $86,1 \%$ \\
\hline \multicolumn{3}{|l|}{ Pekerjaan } \\
\hline Ibu Rumah Tangga & 22 & $61,1 \%$ \\
\hline Pegawai Swasta & 3 & $8,3 \%$ \\
\hline Wiraswasta & 9 & $25,0 \%$ \\
\hline Pensiunan & 1 & $2,8 \%$ \\
\hline Lain-lain & 1 & $2,8 \%$ \\
\hline Menderita & & \\
\hline \multicolumn{3}{|l|}{ Hipertensi } \\
\hline$<1$ Tahun & 8 & $22,2 \%$ \\
\hline$\geq 1-<5$ Tahun & 24 & $66,7 \%$ \\
\hline$\geq 5-<10$ Tahun & 4 & $11,1 \%$ \\
\hline
\end{tabular}

Tabel 1 Distribusi Karakteristik Responden

Tabel 1 menunjukkan distribusi karakteristik responden mayoritas berjenis kelamin perempuan sebanyak 31 responden $(86,1 \%)$, berumur $45-59$ tahun sebanyak 17 responden $(47,2 \%)$, status perkawinan menikah sebanyak 24 responden $(66,7 \%)$, berpendapatan $\leq 2.271 .500$ sebanyak 31 responden 
$(86,1 \%)$, pekerjaan ibu rumah tangga sebanyak 22 responden $(61,1 \%)$, lama menderita hipertensi $\geq 1-<5$ Tahun sebanyak 24 responden $(66,7 \%)$.

\section{Stress dan Tekanan Darah}

Hasil penelitian ini menggambarkan skor minimum, maximum, mean dan standar deviasi stress dan stekanan darah.

Tabel 2 Skor Minimum, Maximum, Mean dan Standar Deviasi Stress dan Tekanan Darah

\begin{tabular}{lccccc}
\hline & N & Min & Max & Mean & SD \\
\hline $\begin{array}{l}\text { Skor } \\
\text { Stress }\end{array}$ & 36 & 13 & 25 & 19,6111 & 2,78032 \\
\hline $\begin{array}{l}\text { Skor } \\
\text { Sistolik }\end{array}$ & 36 & 140 & 202 & 172,1389 & 16,84069 \\
\hline $\begin{array}{l}\text { Skor } \\
\text { Diastolik }\end{array}$ & 36 & 90 & 116 & 100,1944 & 7,57371 \\
\hline
\end{tabular}

Tabel 2 menunjukkan skor stress memiliki nilai minimum 13, nilai maximum 25 dan mean 19,6111 dan standar deviasi 2,78032, skor tekanan darah sistolik memiliki nilai minimum $140 \mathrm{mmHg}$, nilai maximum $202 \mathrm{mmHg}$, mean $172,1389 \mathrm{mmHg}$, dan standar deviasi 16,84069, skor tekanan darah diastolik memiliki nilai minimum $90 \mathrm{mmHg}$, nilai maximum $116 \mathrm{mmHg}$, mean dan standar deviasi 7,57371 .

\section{Analisa Bivariat}

Analisa bivariat pada penelitian ini adalah mengenai hubungan stress dengan tekanan darah pada pasien hipertensi. Untuk melihat hubungan tersebut maka kita lakukan uji korelasi. Setelah dilakukan uji normalitas dengan Shapiro Wilk karena $\mathrm{n}<50$, didapat skor stress dan skor tekanan darah diastolik berada pada distribusi tidak normal, sedangkan skor tekanan darah sistolik berada pada distribusi normal. Oleh karena itu statistik yang digunakan adalah statistik korelasi non parametrik dengan uji spearman. Adapun hasil uji spearman dapat disajikan dalam tabel 3 sebagai berikut.:

Tabel 3 Hubungan Stress Dengan Tekanan Darah Pada Pasien Hipertensi

\begin{tabular}{lc}
\hline \multicolumn{1}{c}{ Hubungan } & $p$ \\
\hline $\begin{array}{l}\text { Hubungan stress dengan tekanan } \\
\text { darah sistolik }\end{array}$ & 0,000 \\
\hline $\begin{array}{l}\text { Hubungan stress dengan tekanan } \\
\text { darah diastolik }\end{array}$ & 0,014 \\
\hline
\end{tabular}

Tabel 3 diatas menunjukkan dengan uji spearmen adanya hubungan stress dengan tekanan darah sistolik dengan $p$ 0,000 dengan $\mathrm{r}$ 0,763 bersifat positif, adanya hubungan stress dengan tekanan darah diastolik dengan $p \quad 0,014$ dengan $\mathrm{r}$ 0,405 bersifat positif.

\section{PEMBAHASAN}

Penelitian ini bertujuan untuk menganalisis hubungan stress dengan tekanan darah pada pasien hipertensi. Karakteristik responden memperlihatkan bahwa yang paling banyak jenis kelamin responden perempuan sebanyak 31 responden $(86,1 \%)$, berumur 45 - 59 tahun sebanyak 17 responden $(47,2 \%)$, status perkawinan menikah sebanyak 24 orang $(66,7 \%)$, pendapatan $\leq 2.271 .500$ sebanyak 31 responden $(86,0 \%)$, pekerjaan ibu rumah tangga sebanyak 22 responden $(61,1 \%)$, lama menderita hipertensi $\geq 1-<$ 5 Tahun sebanyak 24 responden $(66,7 \%)$.

Hasil penelitian menggambarkan skor stress memiliki nilai minimum 13, nilai maximum 25 dan mean 19,6111. Bila ditinjau dari nilai mean atau ratarata, responden cenderung tidak mengalami stress karena rata-rata dibawah $50 \%$. Hal ini kemungkinan dikarenakan sebagian responden mengalami stress yang belum lama. Stress fisik dan emosional menyebabkan kenaikan sementara tekanan darah dimana stress yang sering atau terjadi secara terus menerus dapat menyebabkan hipertropi otot polos pembuluh darah atau mempengaruhi jalur integratif sentral otak. (LeMone et al, 2011; Kozier et al, 2004). Namun bila dipandang dari nilai maximum maka ada beberapa responden yang mengalami kecenderungan stress.

Hasil penelitian menunjukkan skor minimum tekanan darah sistolik adalah $140 \mathrm{mmHg}$, maximum $202 \mathrm{mmHg}$ dan rata-rata sebesar 172,1389 $\mathrm{mmHg}$. Dari hasil ini, menunjukkan bahwa pasien hipertensi rata-rata memiliki tekanan darah sistolik yang cukup tinggi. Berkenaan dengan skor tekanan darah diastolik, hasil skor minimum sebesar $90 \mathrm{mmHg}$, maximum sebesar $116 \mathrm{mmHg}$ dan mean sebesar 100,1944 mmHg. Dari hasil rata-rata tekanan darah sistolik dan diastolik menunjukkan kecenderungan responden berada pada hipertensi tahap 2 (Khatib\&El-Guindy,2005).

Analisis hubungan stress dengan tekanan darah pada pasien hipertensi pada penelitian menggunakan uji statistik korelasi non parametrik dengan uji spearman dikarenakan setelah dilakukan uji normalitas dengan Shapiro Wilk karena $\mathrm{n}<50$, didapat skor tekanan darah sistolik dan diastolik berada pada distribusi tidak normal. Berdasarkan uji spearman mengenai hubungan stress dengan tekanan darah sistolik didapat $\mathrm{p}$ value sebesar 0,000 dengan $\mathrm{r}$ sebesar 0,763 . Hal ini menunjukkan bahwa ada hubungan yang signifikan antara stress dengan tekanan darah sistolik pada pasien hipertensi dengan keeratan hubungan tergolong kuat. Berdasarkan uji spearman mengenai hubungan stress dengan tekanan darah diastolik didapat $\mathrm{p}$ value sebesar 0,014 dengan $r$ sebesar 0,405 . Hal ini menunjukkan bahwa ada hubungan yang signifikan antara stress dengan tekanan darah diastolik pada pasien hipertensi dengan keeratan hubungan tergolong sedang. Hasil penelitian Prabowo (2005) mengenai hubungan stress dengan kejadian hipertensi pada pasien rawat inap rumah sakit dr.Oen Surakarta juga 
memperlihatkan korelasi yang bermakna antara stress dengan kejadian hipertensi dengan $p$ value 0,0001 .

Oleh karena ada hubungan yang signifikan antara stress dengan tekanan darah pada pasien hipertensi, maka perlu dilakukan upaya-upaya untuk mengendalikan stress. Upaya-upaya itu dalam rangka progeam latihan pengelolaan pikiran seperti relaksasi nafas dalam, relaksasi otot progresif, meditasi, senam yoga, dan senam yai chi serta visualisasi.(MaglioneGarveset et al,2005).

\section{KESIMPULAN DAN SARAN}

Hasil penelitian menunjukkan ada hubungan stress dengan tekaaan darah sistolik pada pasien hipertensi, ada hubungan stress dengan tekanan darah diastolik pada pasien hipertensi. Dalam rangka mengendalikan tekanan darah pasien hipertensi, maka disarankan melakukan upaya-upaya dalam mengelola stress yang dialami pasien dalam kehidupan sehari-hari dengan latihan mengelola pikiran seperti relaksasi nafas dalam, relaksasi otot progresif, meditasi, senam yoga, dan senam yai chi serta visualisasi.

\section{DAFTAR PUSTAKA}

Dahlan, M,S., 2009. Statistik Untuk Kedokteran dan Kesehatan, Jakarta : Salemba Medika

Khatib,O,M.N., El-Guindy,M,S., 2005. Clinical Guidelines for The Management of Hypertension, Cairo : WHO

Kozier,B., Erb,G., Berman,A., Snyder,S,J., 2004. Fundamental of Nursing Concepts, Process And Practice, $7^{\text {th }}$ Edition, Pearson Education, Inc
LeMone,P., Burke,K.M., Bauldoff,G., 2011. MedicalSurgical Nursing : Critical Thinking In Patient Care, $5^{\text {th }}$ Edition, Pearson Education

Levenstein, S., Smith,M,W., Kaplan,G,A., 2001. Psychosocial Predictors of Hypertension in Men and Women, Arch Intern Med 2001;161(10) :1341-1346, JAMA Internal Medicine, American Medical Association

Maglione-Garves, Christine,A,B,S,Ed., Kravitz,L., Schneider,S., 2005. Cortisol Connection : Tips on Managing Stress and Weight, ACSM's Health \& Fitness Journal, September-Oktober 2005; Volume 9, Issue 5,pp 20-23

Muttaqin,A., 2009. Asuhan Keperawatan Klien Dengan Gangguan Sistem Kardiovaskuler dan Hematologi, Jakarta : Salemba Medika

Prabowo,A., 2005. Hubungan Stress Dan Kejadian Hipertensi Pada Pasien Rawat Inap Rumah Sakit dr.Oen Surakarta, Thesis, Universitas Diponegoro

Sastroasmoro,S., Ismael,S., 2008. Dasar-dasar Metodologi Penelitian Klinis, Edisi ke-3, Jakarta : CV.Sagung Seto

Sparrenberger,F., Cichelero,F,T., Ascoli,A.M., Fonsoca,F,P., Weiss,G., Berwanger,O., Fuchs,S,C., Moraira,L,B., Fuchs, F,D., 2009. Review. Does Psychosocial Stress Cause Hypertension? A sysrtematic Review of Observational Studies, Journal of Human Hypertension (2009) 23, 12-19, Macmillan Publishers Limited

WHO, 2014. Global Status Report On Noncommunicable Diseases 2014. "Attaining the nine global noncommunicable diseases targets; a shared responsibility", Switzerland : WHO Press 